\title{
Transmission and Transformation: Memories of the Siege of Sarajevo
}

\author{
Ivana Maček
}

More than 20 years have passed since the Dayton Peace Agreement of 1995 for Bosnia and Hercegovina, which began the end of the fouryear-long Siege of Sarajevo. Three-quarters of the pre-war population of Bosnia and Hercegovina, around three million, fled or were driven from their homes, and of these around one million left for 'third countries' outside the former Yugoslavia. ${ }^{1}$ This brought a complicated and fragile peace for both citizens who stayed in the country and those who found refuge abroad. 'By 1994, half of Sarajevo's 600,000 pre-war residents had left the city. Another 150,000 "displaced persons" had arrived, mostly Muslims from villages and small towns in eastern Bosnia'. ${ }^{2}$ While some refugees in third countries were obliged to return to Bosnia and Hercegovina after the war (Germany, for instance, had a policy of compulsory return), others, including refugees in Sweden, were left with a choice. Some people returned to their homes; others resettled in territories that were now under the military and administrative control of 'their' ethnonational group. ${ }^{3}$ The vast majority of refugees in Sweden,

This project was financed by the Swedish Tercentenary Foundation (Riksbankens jubileumsfond).

I. Maček $(\square)$

Stockholm University, Stockholm, Sweden

e-mail: ivana.macek@socant.su.se

(C) The Author(s) 2018

A. Dowdall and J. Horne (eds.), Civilians Under Siege from Sarajevo to

Troy, https://doi.org/10.1057/978-1-137-58532-5_2 
however, chose to remain, as they felt that they had better opportunities there than if they were to return to Bosnia and Hercegovina. ${ }^{4}$

In 2013-2015, I followed the families of more than 20 people who left Sarajevo for Sweden because of the siege. I was interested to see what significance experiences of the siege now have in the lives of the parents who were there, as well as for their children, most of whom were born in Sweden. In this chapter, I have chosen to focus on one family in order to examine important phenomena connected with the intergenerational transmission and transformation of the parents' experiences to the next generation. ${ }^{5}$

Comparison with the results of a similar study done a few years ago in Sarajevo suggests that living in Sweden shapes the ways the siege is remembered and understood today. ${ }^{6}$ Another important factor is how the siege is narrated. ${ }^{7}$ As I myself did anthropological fieldwork in besieged Sarajevo, my interlocutors knew that I had experienced the siege, albeit from a different position than themselves. For the grown-ups, this fact connected us through common experience. For the children, I occupied a position similar to their parents. The fact that I come from the former Yugoslavia, have lived in Sweden since 1990 and have a son born in Sweden after the war also made our life experiences similar. I believe that these commonalities opened doors that would otherwise have remained closed and enabled me to offer an account of the transmission and transformation of parents' experiences of the siege of Sarajevo in Sweden.

\section{The Porous Siege}

The siege of Sarajevo lasted from spring 1992 to spring 1996. During the ensuing 20 years, the majority of pre-war residents who fled have not returned permanently. When I talked to Sarajevans in Croatia in the 1990s, as well as during the past few years in Sweden, many said that they left 'on the last airplane' or 'with the last bus convoy'. The flight of Sarajevans from the town in early April 1992 was substantial, helped by what was left of the former Yugoslav army, but people also left later, when the front lines surrounding the town had been established and the siege was tighter. ${ }^{8}$ As one young woman I befriended during the siege told me in 1994, 'anyone who wanted to could leave'. In other words, the siege was porous: people could move in and out, albeit with difficulty. If you wanted to leave, you needed good contacts with all three armed groups involved: the HVO (Hrvatsko vijeće obrane, Croat Defence Council, Bosnian Croats' Army), the ARS (Armija Republike Srpske, Bosnian Serbs' 
Army) and the ARBiH (Armija Republike Bosne i Hercegovine, Army of the Republic of Bosnia and Hercegovina, the army of the Bosniakdominated government). ${ }^{9}$ Paying bribes to all three was often necessary. The porousness of the siege also meant that goods could pass into the town, creating a flourishing black market. ${ }^{10}$ Especially after the opening of the tunnel under the airport runway, which was under the control of the Muslim-dominated government of Sarajevo, opportunities for relatively safe government-sponsored departures and returns were considerably increased. ${ }^{11}$ Finally, one of the harshest aspects of siege life was the rupture of communications with the outer world. The telephone lines were cut, and there were few expensive satellite phones and fax machines; amateur radio broadcasters had only a few crackling connections; some messages passed through the Red Cross on their standard-form letters; some private parcels came through humanitarian organizations. ${ }^{12}$

In many families, the women left first, taking the children with them, while the men stayed. Men had a military obligation and needed extra papers to leave. Moreover, people reasoned that hostilities would not last longer than the summer, so someone should remain to protect the apartment from being occupied by refugees and to hold onto the family's position in local society. When it became clear that the hostilities were prolonged and unpredictable, and that participation in armed units meant not only defending the hometown but also being sent to frontlines elsewhere in Bosnia and Hercegovina, fighting a war that most saw as senseless and not in their own interests, the men also began to leave. ${ }^{13}$ Most of the families that I have met in Sweden today left the besieged town in this way and settled in Stockholm, the Swedish capital.

In order to understand the ways in which the siege has been transmitted and transformed in the Swedish context 20 years after it ended, I take a close look at a middle-class urban family. Vesna and Nenad were both born in Sarajevo; they were already a couple before the war; when the war started, they had just begun their first jobs after completing their studies and were still living with their respective parents. ${ }^{14}$ After leaving the town separately, they settled in Sweden where they married and had two daughters.

\section{The Perilous Siege}

The younger daughter, Daniela, aged 15, knew very little about the war because, as she told me, her parents did not talk much about it when she was a child and had only just started talking more now that she was older. 
When she was younger she imagined the war as constant shooting, but now that she thought about it, she realized that there could not have been shooting all the time, and she could not really understand how life functioned in wartime. Regarding the siege of Sarajevo, she knew from her grandmother that they had neither food nor electricity and that her grandfather worked as a doctor in the hospital. About her parents' life in wartime she knew nothing, except that 'it was not good' and that 'it was not easy'. She was slightly embarrassed about not knowing more. When I asked her to try to imagine how it was for them, she said that they must have felt a lot of fear and discomfort. Her mother left, she thought, because she could live a better life in Sweden. When I asked why her father stayed longer, she said that he probably thought that he could live there but after some time he realised it was impossible.

Although Daniela's knowledge of the siege was very limited and mostly generic, it included both transmissions and transformations of some key themes in this family's experiences: the danger and low standard of living, and the sense that the situation was surreal and incomprehensible. She was not aware of the particulars of her parents' experiences during the siege, or of why and how they decided, attempted and finally managed to leave.

Her older sister, Ida, aged 18, knew more about these themes. She said she knew some 'details' about the siege, but what she actually knew was mostly what had happened to her parents, not how it happened and how they felt about it. By referring to her parents' experiences as 'details', she meant that she did not have a broader picture of the siege. When the parents, sometimes both and sometimes individually, told me about the events that Ida knew about, their stories were richer and often had a different focus. I call these narrated memories 'family stories' and analyse whether and how they have been transmitted and transformed. ${ }^{15}$

While Daniela struggled to understand what it meant to live with intermittent, but lethal, shooting, Ida must have heard a story about a neighbour who was killed during a heavy bombardment in front of the apartment block where her mother lived. 'Mum and Dad did tell me ... How their neighbours were shot in front of them and how the grenades were falling constantly. I mean, in Sarajevo you can still see. All that is not yet repaired, there is still a lot of [damage] there, the holes.'

In the parents' version of this family story, it was a rather more absurd occasion. The young couple was in town and came back to where Vesna 
lived with her parents. Her mother told them that the water had just come on and she had warmed the boiler, so Nenad should take a shower. This was embarrassing as he was not often there; it felt a bit too intimate. But hot water was a rare luxury, and he decided to accept the offer. ${ }^{16}$ Vesna described what happened:

Exactly when he started to take a shower, a shell blew up exactly where we had passed. A man who vulcanized tires was there, standing there where he usually worked, and was killed. Everything was shaking; I think that was when our windows in the kitchen shattered. And [Nenad] heard that it exploded [laughter]. I think that one shell hit the building, one in front of it, and one more. Three all at once. But there is hot water, and he is taking a shower. Should he stop, or not? Ah, I will not stop. And he continued to take a shower. And we lay down. I mean, shrapnel was whizzing in the kitchen ... [Seriously] Shrapnel was actually the worst.

She told this story with a characteristic combination of laughter at the absurdity of the situation, seriousness in the face of the existential danger they lived with every day, and a sort of quiet wonder and sadness over not wanting to think about it, much less tell her daughters.

When we look at the transformation of this experience in the daughters' telling, we see that 'one neighbour' who was killed became 'neighbours', that talking to him half an hour earlier became 'shot in front of them', and an apartment block exposed to intermittent shelling became 'grenades were falling constantly'. This tendency to expand the scale of events is similar to Daniela's idea that 'there was shooting all the time'. In the children's imaginations, the violence and destruction become more all-encompassing and dramatic. The absurd and embarrassing part about their father standing in the shower soaped from head to toe while their mother's family was lying on the floor to avoid the shrapnel was not part of the children's narrative. Perhaps they had not been told that part of the story or did not understand it because they were too young; perhaps they did not realise that the joy of showering, even under such circumstances, had some dignity as a memory of the siege. The joy, absurdity and humour become incomprehensible and disappear from the children's stories. ${ }^{17}$ Thus, the stories are transformed. Some parts of the experience are lost in the transmission. But others, such as the closeness of lethal danger and the fact that the family survived by sheer coincidence, are caught quite precisely by the children. 
Significantly, Ida connected the parents' story to something that she had experienced herself during her visits to Sarajevo: the visible holes left in asphalt and buildings by exploding shells. For children born after the war and living abroad, these tangible and poignant remains of the war are often their only material connection to their parents' experiences. These traces are thus filled with the children's imagination and feelings of unease in the face of their parents' past. ${ }^{18}$ Because this past is cognitively incomprehensible, the fear and existential anxiety that some children describe do not stem from memories of the war as a lived experience but from an imagined, 'secondary memory'. ${ }^{19}$

Another example of the transmission and transformation of family stories involves a narrow escape. Ida recounted her father's story of a time he was supposed to go over a bridge, but felt he should not. She stated that 'later that same day many, I do not know whether it exploded or [what, but] many people were killed on that bridge'. Nenad described the same episode:

They killed that guy in front of me. When I was coming back from work. There was one little bridge, towards this house of mine, where the number two tram turns. And the sniper always shot here, on this bridge. And now I stood by that bridge. I never liked to run across a road when many people were running. Many people run, you know, it will hit someone, and with the luck I have, it will hit me. Instead, you know, I always wait somehow to be alone. And I said okay, I will wait. And I waited, and waited, and waited there. And as I waited to pass, only a 'swoosh' [sound of a shell] and 'boom' [sound of an explosion].

The daughter had correctly caught her father's intense emotional experience, the sense that he had once again escaped death only by chance mixed with the horror of witnessing the death of a man who just a minute before had been standing beside him. Yet some salient details in her version differed; for example, the solitary man who lost his life became 'many people'. Moreover, her father's customary strategy for crossing the local bridge, which happened to save him that day, was transformed in her account into his intuition of particular danger. In the daughter's version, her father had an almost magical, even godlike, foreknowledge that saved him, while in his version death was random. ${ }^{20}$ This shift might reflect the general tendency of children to imagine their parents as omnipotent and invulnerable, which provides them with a sense of security while growing up. Perhaps these parents, who valued decisions based 
on knowledge and unbiased inquiry, had tried to protect their children from-or had no way of telling them about - the randomness of fatalities during the siege. ${ }^{21}$ Given the difficulty of communicating the intermittency of violence and their own vulnerability, many parents try to avoid 'burdening' their children by sharing their experiences of war.

The parents' accounts often included comments about their relationships with people with whom they shared, or from whom they received, food. They also conveyed their disappointment when people whom they thought would help did not do so and their delight when others assisted them unexpectedly. Nenad recounted numerous examples of people who helped him by sending food parcels from Belgrade, and one aunt who, inexplicably and distressingly, failed to do so. A man whom he knew from his student days and a man from Japan whom the couple had befriended before the war had managed to send parcels through the local church, as his aunt could well have done. People helped the family with the documents, permits and passports needed to leave and paid for their places in a convoy. During the siege, Sarajevans told me of receiving help unexpectedly, as well as their disappointment in people they had trusted. The main point was always the same: in war, people's true character is revealed. ${ }^{22}$

Stories of hardship were complemented by stories of triumphantly overcoming difficulties. One story that was particularly important to this couple, which they both told me, was when Nenad managed to call Vesna in Sweden by phone from Sarajevo. His boss and business partner had an ingenious idea of making small telephone central exchanges use the few and expensive satellite connections that existed in the town. He sold this idea to an important state institution and a large industrial firm, and while they were installing or repairing these connections he managed to make free calls to Sweden under the pretext of having 'to check whether the connection is working properly'. Nenad's story is more detailed and contains dramatic moments that could have jeopardised his attempt to put through a call, but both he and Vesna expressed pride in his and his partner's ingenuity, as well as amazement over the abnormal situation that made an otherwise simple thing such a feat. ${ }^{23}$

As these examples reveal, parents turn the most dramatic events into family stories. For children without any wartime experiences of their own, these stories form their knowledge of the siege. While some aspects become more dramatic and others are omitted, the emotional values of the stories are transmitted to the children. When children recount 
what they know about their parents' experiences, however, they express mainly respect and shock, while their parents display humour, joy, anger and sorrow as well. Moreover, children interpret their parents' stories through their own experiences and context. Thus, seeing the traces left behind by exploding shells helps children imagine their parents' experiences of war, forming secondary experiences and memories.

\section{LeAving THE Besieged Town}

Some of the family's most dramatic stories concerned their efforts to flee the besieged town. While Daniela did not know anything about her parents' experience of leaving, Ida talked about it in vague terms:

It was a rather complicated situation. And in the end they managed to get everyone ... out of Sarajevo ... to leave Sarajevo, by some truck or whatever it was. They put themselves on some kind of a list somewhere. I do not know, I heard something that the UN was supposed to help somehow, but that it didn't and in the end it turned out, somehow, that it did not do anything good, though I do not know exactly what and how.

Ida mixed together different family stories, and the facts were not exact. But she grasped the process of getting their names put on a list and undertaking perilous journeys through the siege lines, as well as the sentiments conveyed by her parents' stories. She also knew that their attempt to get her mother out of the town with the help of the United Nations High Commissioner for Refugees (UNHCR) had failed. The daughter's story ended there, but both parents told me that while returning from the UNHCR offices they had a close brush with death.

'We could have got killed that time,' Vesna said. As it was a long way into town, they started hitch-hiking. But massive shelling hit a nearby market, and they saw cars speeding along what was called Sniper Alley with bloody bodies hanging out of them. When a car stopped they jumped in, but immediately realised that the driver and his companion were members of an extreme Croat nationalist militia. The men asked them about their nationality, but as their names sounded Christian they did not bother them. The couple were terrified, but the men let them off at a crossroads near their home.

In addition to this dramatic episode, Vesna's account of trying to leave Sarajevo included her family's failed attempt to get help through a 
local war thug. Both she and Nenad told me how he eventually managed to put her on a list for 'the last' Red Cross convoy with sick people leaving the town after her father's colleague provided her with a fake diagnosis of a serious illness. Recounting her 20 hour journey meant reliving the horror, fear and sorrow she had felt, as well as the perilous but essential act of taking matters into her own hands, which took an emotional toll that Vesna found surprising. Nenad, too, told me about his dangerous escape attempts, which nobody else in the family mentioned, as well as his long journey through numerous checkpoints. Significantly, the children did not mention, and probably did not know about, their parents' most frightening experiences while trying to leave the siege.

The importance of the story of the failed attempt to leave the town with UN help has been transmitted to Ida, but its meaning and emotional quality had been transformed. While the parents expressed contempt for the UN and its officials, the elder daughter described its failure matterof-factly. But she understood that this failure could have had fatal consequences for her parents: 'And I know that there was a massacre, in ... What was the name of the place?' Thinking that she meant one of the massacres in Sarajevo that finally provoked world opinion to press for the ending of hostilities, I asked, 'On a market, or ... ?' 'No,' she replied, 'in another town. Something "Srebrnica”, something.' 'Ah! In Srebrenica,' I said. 'Yes,' she confirmed. 'That it was really there, that many people were killed ... I really don't know any more ... I mean, it has passed, what, twenty years, and it is still very ... very ... The subject is still not ... It is still very much a taboo.' The association between the UN failing her parents in particular and the people of Bosnia more generally by permitting a genocide suggests the scale of her parents' negative emotions towards the UN. While the emotional scale is accurately transmitted, the content is transformed in accordance to Ida's own understanding of the UN's moral obligations. In her moral universe, the failure to help a young couple exit the siege does not seem massive enough to cause such indignation, but a failure to prevent a genocide is.

This shared family opinion of the UN's betrayal goes hand in hand with their outspoken view that you need to take responsibility for your own life and cannot depend on others. Had they relied on the UN or Bosnian politicians, they would live today as people in Sarajevo do: in a country that does not function, with almost $50 \%$ unemployment, a low standard of living and an undemocratic political system plagued by national animosity. This assessment is entirely compatible with cherishing 
all those people, whether family, friends or colleagues, who helped the parents accomplish their plans. But nothing would have happened without their own efforts and capacities.

While the parents were still angry and cynical towards the UN, Ida was engaged in efforts to assist refugees, and her parents were proud of her activism. She was also very concerned about nationalistic and neo-Nazi movements in Europe today. Parental values have been transmitted, but their anger and cynicism have been transformed into altruism and solidarity. Natan Kellerman has reported that, in a similar way, the children of Holocaust survivors are not simply hampered by their parents' experiences; their secondary experiences could also be a source of strength. ${ }^{24}$

Another constructive consequence of the parents' experience is the daughters' strong commitment to do well in their own work, currently as students and soon as professionals. The motivation, in the children's eyes, is a good standard of living and all the choices and freedom that this brings. Their parents stand as living exemplars of the advantages of education. Their parents' guidance on how to solve problems and overcome obstacles in life serves as an example for them to follow. As their parents were successful professionals even before the war, this capacity would have been transmitted to the daughters in any case. However, the children accept their parents' success in overcoming their war experiences and fleeing to a country where they knew almost no one and had to start again from scratch as unquestionable evidence that they held the right values.

\section{The 'Unnecessary' Siege}

While talking about what she knew about the siege through her parents' experiences, Ida spoke more quietly than usual, sensitively and carefully, almost as if she were handling something fragile. Was it, perhaps, out of respect for the impossibility of imagining life during the war, despite the palpable evidence of shell explosions on the city's surfaces? Both during and after the siege, Sarajevans described the almost surreal quality of life in the town. ${ }^{25}$ This sense of incomprehensibility has been passed on to a generation born far from Sarajevo. Ida concluded tiredly that the war had been 'unnecessary'.

When explaining to me why she did not know more about the war, Ida said that her parents did not talk a lot about it, because they did 
not want to give the daughters an oversimplified picture of something so complicated. She thought that the war was still a sensitive subject for her parents, so she was reluctant to ask them much. 'But I am interested. I will find out,' she said confidently. 'I can look up things myself now.' A moment later, she admitted, 'But I do not know where to start.'

Vesna told me that she deliberately did not tell her daughters anything about the war when they were younger, and even now she lets them form their own understanding of the situations they encounter while visiting Bosnia. She realizes that, as her daughters grow older, they discuss certain topics that they previously had not, but mostly in general terms and informed by the situation in Sweden. The parents have told the children some 'anecdotes', she said, mostly during long drives from Sarajevo to the Croatian coast during summer holidays. Her daughters sometimes got angry at their parents for not telling them more: 'Why do we not know this? Why haven't you told us?' Vesna was curious, though, about what they might have conveyed to their children 'indirectly', 'without being conscious of doing it', as she put it.

Nenad said that he did not tell his daughters stories about his lucky escapes from death:

I do not know whether there is a need and a reason [pause]. Perhaps there is. One needs to know what had happened in order to be able to go on. On the other hand, why should I burden them with some things? Let them live their own lives, and if at some point it will be necessary to sit down and talk, we will talk, like, how it was, how it will be.

Almost without taking a breath, however, he angrily described the war as motivated exclusively by greed for power and money:

I definitely think that the whole war down there is crazy and so idiotically organised. Like, here they say that it is a war on a religious basis, that there are different peoples/national groups [narodi]. That is an empty story for fools [ $\check{s} u p l j a$ prič $a]$. I mean, that is so simplified, all that. There are only two reasons. That is, rule and money. So someone has the power and in that way provides for themselves; they steal the money to provide for themselves.

His anger at this pervasive greed and at the false explanations of the war has been transformed into Ida's quiet and sorrowful assessment of the war as 'unnecessary'. Neither of his daughters clearly expressed his view that the war was about power and money. 


\section{Reorienting Priorities as a Consequence of the Siege}

When I asked Ida whether she thought that the war had any influence on her family, she said that her parents did not care much about material things or petty conflicts with unimportant people; they valued family much more, as well as the close friends whom they treated like family. They also developed a more open and accepting understanding of other people's choices during the war, not excusing them, but rather understanding why they acted in ways that they themselves would not have. This enabled them to maintain relationships with some relatives.

Nenad explained, 'There are two good things about war. Everything else is bad ... One good thing about the war is that you see who is who. People show their real faces. And the other thing that is good with war is that things come into perspective. What is important, what is less important.' He offered numerous examples of material things that were destroyed in the war but did not really matter. He also argued that it is useless being stressed at work and thinking only about what one might have done or might have had rather than appreciating what one has. It was easy to fall into this trap in Sweden, he felt, which led to constant dissatisfaction.

Nenad's and Ida's accounts of the positive consequences of wartime experiences concurred: the war brought a broader understanding of other people, a sense of the special value of friends and of social and emotional ties with relatives, and it set priorities straight-no materialism, no petty quarrels.

When I asked Nenad whether he was concerned about what his daughters might think or was anxious that they do not get any episode 'wrong', he told me about his mother's relatives who live in Serbia and whom they visit regularly. One of his mother's brothers, whom he liked a lot, turned out to have been an officer in the Serbian army during the war in Bosnia. Nenad had been troubled by this fact, but after a lot of thinking concluded that this part of the family could not help becoming indoctrinated by wartime Serbian media propaganda. He also remembered, that as a child he had seen, and thought absurd, a national Romantic painting hanging in his Serbian relative's home of an ancestor who had 'heroically' died after slaughtering twenty Turkish soldiers. But then he added that, although his dear uncle was indoctrinated, some of his female cousins organised demonstrations in Serbia against the war in Bosnia and one of them was nearly arrested. He concluded: 
All people are not the same. [Some say that] on the one side of Drina all are Četnici [Chetniks, derogatory term for Serbian nationalists], on the other side of Drina all are Balije [derogatory term for Muslims]. It is not like that. Everyone is for oneself alone and everyone decides for oneself how to relate to oneself, and to the others, and to one's surroundings. Absolutely. There is no question about that. I have my opinions about that war; perhaps they are good, perhaps they are bad, but they are mine. And so, I can talk with everyone.

His answer points to the complexity of the war and of peoples' reasons for making particular choices. This knowledge has been transmitted to, and understood by, Ida.

His statement also displays his convictions regarding personal responsibility for one's attitudes and choices, which was clearly transmitted to his daughters. Another life strategy that the daughters learned from their parents, despite their anger over the war's destruction of their way of life, is rationality and trust in well-grounded knowledge. As their father said:

So much insanity in all of it ... That is madness, complete madness. And for whom? For a few idiots who went and drew maps and divided [the whole country]. Milošević and Tuđman and Alija Izetbegović [the nationalistic leaders of Serbia, Croatia and Bosnia, respectively]. Altogether, all three of them. And Kučan [Slovene president during the dismemberment of the former Yugoslavia] nicely said, this cannot work. And he was right. Had they listened to the Slovenes this shit would not have happened. If they had listened to that Ante Marković [the last Yugoslav federal prime minister]. The man was an engineer. He came [and said]: we have a problem. This is how the problem is solved. Let's work. But no. The herd [stoka] needed a cowboy [čoban] to tell them what to do. I don't know. Two per cent. Two per cent of the votes [went to the non-nationalist party of Ante Marković]. I cannot get over it.

\section{Nationalism and Nostalgia Before and After the Siege}

Although Daniela's school class had discussed how fear can make people seek security in group belonging, they had not specifically studied the Bosnian War. Nonetheless, she had some ideas about how nationalism shaped the conflict in the former Yugoslavia. She knew that after President Tito's death politicians could not agree on how to divide territories into new countries and that this was the cause of the war. Her 
father's anger at the three main nationalist politicians seems to have convinced her that they were the culprits who caused the war.

By age 18, Ida had been exposed to more information in school. She had learned about 'Greater Serbia' and the beginning of the First World War. However, she recognised Swedish bias in the portrayal of these events, as the organisation that lay behind the assassination of Archduke Ferdinand in Sarajevo was called 'terrorist'. She also objected to the former Yugoslavia's long-term president being called a 'dictator'. Her father's contempt for nationalism was expanded to contempt for simplistic historical and political interpretations.

Both daughters maintain that their parents encourage them to think logically and independently, and to formulate opinions only after collecting information and asking people about their experiences and attitudes. Ida thought that, although the former Yugoslavia was not perfect, with a one-party system and Communism, the country functioned and life there had been good. All this stands in stark contrast to Bosnia and Hercegovina today. This 'Yugonostalgic' view is shared by almost all prewar Sarajevans, whether they were children, youths or grown-ups, and whether they left, stayed or returned. ${ }^{26}$

Although memories of the lives they had lost did not hamper members of this family, they did cause the parents anger and deep and unhealed sorrow. Vesna only displayed clear anger once, when I asked her how she related to the war:

That was also very hard for me, that someone took my country, which I loved very much. They took my identity. Somebody decided that that identity does not exist anymore. Since I come from a mixed marriage, I was a Yugoslav. I really felt like a Yugoslav. I mean, there existed no other option for me. And I was very proud of my Yugoslavness and that somebody should that simply take it from me ... that was a loss. That was a big loss for me. And it took me a long time to make some kind of new identity, and I still cannot really.

This huge loss of identity is something that all Sarajevans who left the town as grown-ups have reported on many occasions, sometimes with anger and sometimes in sorrow.

Like his wife, Nenad was deeply upset by national divisions in Bosnia today. He told me the names-Croatian, Serbian and Muslim-of his 
closest friends and business partners at the outbreak of the war who were now living in Zagreb and in Canada. 'Well if that was a ključ, I really know nothing,' he concluded with frustrated laughter. The former Yugoslavia, particularly Bosnia and Hercegovina, had a quota system called ključ by which all national groups had a right to equal representation in governing and administrative bodies. Proponents of nationalism have suggested that the quota system was an artificial way of showing that all peoples were justly represented, while in fact some national groups were discriminated against and the national blending of the population was merely a Communist myth. Nenad's anger and agitation were a reaction to this nationalistic attitude, because his example showed that people actually did mix. 'It was a natural ključ,' he reiterated. 'People found each other and worked together. There were absolutely no problems. What problem did they have to make business together? There was no problem for us to socialise. There were many like this, and like that. All nice, good people. I mean.' He paused. 'Terrible. I simply cannot get over it.'

Then he spoke about the assumption, which he often encountered in Sweden, that the war was based on religion. After some ironic comments about the unimportance of religion in his life, he told me about Vesna's grandfather, who was an Orthodox priest in Banja Luka (one of Bosnia's larger cities, now in Republika Srpska) after the Second World War. 'Every morning he, his colleague fratar [Catholic Gray Friar], who lived next door, and their colleague imam [Muslim priest], every morning they drank coffee together. The three of them. After the Second World War.' He reiterated this description several times. 'I say, the hell, if, after the Second World War, when the Communists won, were in power, and all, the three of them could all sit and drink coffee, why should not people do the same now?' He continued: 'And then they say, here they tell me that this is a religious war. Come on.' He paused. 'It is such a joke that it is unbelievable. The time that it will take that country to recuperate is a catastrophe. It is ... [pause] It is a historical mistake.'

The children do not share this sense of tremendous loss. In this family it has been transformed into an understanding of and respect for the parents' need to reconnect with family and people in Sarajevo. The children imagine that life in the former Yugoslavia was good, but their life experiences and opportunities in Sweden exceed anything they see in Bosnia and Hercegovina today. 


\section{CONCLUSION}

Focusing on the family of one couple that lived through the siege has allowed me to analyse the transmission and transformation of their experiences to their children-their daughters born in Sweden. This family's experiences, choices and attitudes, although in some respects unique, have much in common with the majority of families in Sweden with experiences of the Sarajevan siege.

The emotional charge in the parents' stories conveys to the children that what is being said is of existential importance. However, the content of what is told changes, and the focus shifts in the children's understanding in accordance with their own lives and experiences. In Sweden, international solidarity, anti-racism and altruism are promoted as morally correct attitudes, even though today the social-democratic government is under pressure to stop the influx of refugees and nationalistic and xenophobic sentiments are gaining ground. Daniela's understanding of nationalism as the malign force behind the dismemberment of the former Yugoslavia is thus congruent with the Swedish middle-class urban context. Ida's awareness of different perspectives and biases, and the need that both daughters feel to think for themselves, have been promoted both by their parents and by the Swedish school system. Nenad did not wish to communicate to his daughters his view that power and money were responsible for the conflict, because questions of what caused the war-and thus moral responsibility for it-are still highly politicised in Bosnia and Hercegovina today. At the same time, the daughters' understanding that the picture they are given in Sweden is false and simplistic, and that nationalism is stupid and prejudiced, was transmitted without transformation from their parents. The daughters' absorption of this view was facilitated by the predominance of tolerance and democracy over nationalism in contemporary Swedish political discourse.

Some of the emotional qualities attached to the parents' attitudes have, however, been transformed by the daughters. The parents' anger and sorrow has become the daughters' interest and sense that they should know more, coupled with their respect and internationalist engagement. The parents' references to Sarajevo, Bosnia and the former Yugoslavia have been widened to encompass the global arena their daughters were raised in-not only because their only two cousins live in Australia and because Sarajevans today are to be found worldwide, but also because of Sweden's international orientation. 
At the same time, other emotions and some specific facts have been partly lost or transformed. The violence, destruction and precariousness of life during the siege loom larger and are more dramatic in the daughters' stories than the parents'. Parts of stories that were absurd and humorous are missing from the daughters' stories, as is the parents' sense of utter helplessness and the irrationality of destruction.

If we compare these findings with Kalina Yordanova's research in post-war Sarajevo and Carol Kidron's studies of the children of Cambodians in Canada and of European Jews in Israel, we can see both some shared and some distinct phenomena. ${ }^{27}$ One common phenomenon is the appearance of 'family stories', in which emotionally charged experiences are often turned into moral lessons and existential attitudes. The transformation of parents' direct experiences into generic, yet more dramatic, 'secondary memories' of children is another general phenomenon. Many differences between these cases are due to differing post-conflict situations and the contexts in which the children grow up. Refugees' children in Sweden enjoy more favourable circumstances than those in Canada, Israel, and Bosnia and Hercegovina. Not only is the social welfare system advantageous, even for newcomers, but some key political values were easily transferred from pre-war Bosnia and Hercegovina to contemporary Sweden. In Canada, Cambodian refugees occupy poorer socioeconomic positions, while in contemporary Bosnia and Hercegovina social solidarity and respect for differences are almost extinguished.

The nature of the conflict has an effect as well. In both Israel and Bosnia and Hercegovina, the constant presence of nationalist unrest and threats of violence create an unstable political and existential context. In Sarajevo, since the war, many organisations have engaged in helping people with post-traumatic stress disorder (PTSD), so one of the few ways of providing for one's subsistence has been to stress the disabling symptoms that the war had caused, thus encouraging parents to hold on to the traumatic side of their war experiences. In contrast, not only is Sweden a stable country, but even parents with PTSD have tried to minimise the symptoms, and their traumatic past has not been transmitted to their children as 'secondary traumatisation'. Yordanova's study in Sarajevo shows remarkably higher levels of both parents' PTSD and children's secondary traumatisation than in families with comparable experiences of adversity that I have studied in Sweden. 
Another important difference is the nature of post-conflict contact with the country of origin. Here, the Swedish case is unique: families travel regularly and relatively frequently to the parents' places of origin. Parents' nostalgia and children's fantasies are corrected by confronting the Bosnian reality. Both parents and children appreciate the warmth and close relatedness to other people that still exists in Bosnia, but the drawbacks, such as poverty and nationalism, are much stronger, which keeps them firmly grounded in Sweden. Comparison with the stark disillusionment of Palestinian children described by Gatrell shows the importance of the nature of transnational post-war contacts. ${ }^{28}$

Ultimately, however, the nature of the conflict that the parents lived through - a prolonged siege over several years - generated a process of disillusionment, from the first phase of bewilderment and spite towards 'primitivism', through the normalisation of violence and discrimination, to an insight that the life they were used to had been forever lost. This context helped to shape both the transmission of memories to their children and the transformations that those memories would undergo.

\section{Notes}

1. UNHCR Office of the Special Envoy for Former Yugoslavia, Information Notes on Former Yugoslavia, 8/94 (1984).

2. Ivana Maček, Sarajevo under Siege: Anthropology in Wartime (Philadelphia, 2009), 86.

3. For the explanation of the term 'ethnonational' and the relation between national, ethnic and religious belonging and identification in Sarajevo, see Maček, Sarajevo, 124. The Dayton Peace Agreement recognised three national groups as constitutive in Bosnia and Hercegovina: Bosniaks, Serbs and Croats.

4. Around 40,000 refugees from Bosnia and Hercegovina came to Sweden in the early 1990s. On the difficulties of returning to Bosnia and Hercegovina, see Stef Jansen, 'Troubled Locations: Return, the Life Course and Transformation of Home in Bosnia-Herzegovina', in Struggles for Home: Violence, Hope and the Movement of People, ed. Stef Jansen and Staffan Löfving (Oxford, 2008), 43-64. On returns from Sweden, see Melita Čukur, 'Dilemmas of Return-Two Anthropological Case Studies', in Returning Home: An Evaluation of Sida's Integrated Area Programmes in Bosnia and Herzegovina, ed. Melita Čukur, Kjell Magnusson, Joakim Molander and Hans Skotte (Stockholm, 2005), 47-100; Marita Eastmond, 'Beyond Exile: Refugee Strategies in 
Transnational Contexts', in Forced Migration and Global Processes: A View from Forced Migration Studies, ed. F. Cre'peau, D. Nakache and M. Collyer (Lanham, Maryland, 2006), 217-236. On returns to Sarajevo, see Anders H. Stefansson, 'Refugee Returns to Sarajevo and their Challenge to Contemporary Narratives of Mobility', in Coming Home? Refugees, Migrants, and Those Who Stayed Behind, ed. Lynnelyn D. Long and Ellen Oxfeld (Philadelphia, 2004), 170-186. Note, though, that this decade-old research describes the choice to return or stay as an open-ended process of keeping open as many options as possible. My contemporary materials from Sweden show a different kind of dynamic: people have chosen Sweden as their permanent place of residence, while their short visits and longer stays in Bosnia and Hercegovina are predominantly of a social nature. Several excellent ethnographic accounts of life in post-siege Sarajevo give a more substantial picture of its current problems and the reasons why it compares mostly unfavourably to life in Sweden in the eyes of my interlocutors: Ioannis Armakolas, 'Sarajevo No More? Identity and the Sense of Place among Bosnian Serb Sarajevans in Republika Srpska', in The New Bosnian Mosaic: Identities, Memories and Moral Claims in a Post-War Society, ed. Xavier Bougarel, Elissa Helms and Ger Duijzings (Aldershot, 2007), 79-100; Anders H. Stefansson, 'Urban Exile: Locals, Newcomers and the Cultural Transformation of Sarajevo', in New Bosnian Mosaic, 59-78; Fran Markowitz, Sarajevo: A Bosnian Kaleidoscope (Urbana, 2010); Elissa Helms, Innocence and Victimhood: Gender, Nation, and Women's Activism in Post-War BosniaHerzegovina (Madison, 2013); Keziah Conrad, 'Dwelling in the Place of Devastation: Transcendence and the Everyday in Recovery from Trauma', Anthropological Theory 14 (2014): 74-91; and Stef Jansen, Yearnings in the Meantime: 'Normal Lives' and the State in a Sarajevo Apartment Complex (Oxford, 2015). See also writer Aleksandar Hemon's account: 'Izvještaj o posjeti Potomstva Sarajevu (A Report from Offspring's Visit to Sarajevo)', 9 May 2009, http://pescanik.net/izvjestaj-o-posjetipotomstva-sarajevu/ (accessed 14 June 2009).

5. I focus here on some typical experiences of the siege of Sarajevo, but without attempting to cover it in all its complexity. My book, Sarajevo, presents a full ethnography.

6. Kalina Georgieva Yordanova, 'Intergenerational Transmission of Traumatic Experience in the Families of War Survivors from Bosnia and Herzegovina', PhD diss. (University College London, 2014).

7. On the importance of context and memory in 'stories' and personal narratives, see Marita Eastmond, 'Stories as Lived Experience: Narratives in Forced Migration Research', Journal of Refugee Studies 20 (2007): 248-64.

8. Maček, Sarajevo, 89-91. 
9. For a popular joke about this, see ibid., 168.

10. Peter Andreas, Blue Helmets and Black Markets: The Business of Survival in the Siege of Sarajevo (Ithaca, 2008); Maček, Sarajevo, 66-8, 79, 81-2, 84, 98.

11. Maček, Sarajevo, 27.

12. My ethnography of the Sarajevan siege is filled with examples of the precarious, yet possible, communication channels with the outer world.

13. Maček, Sarajevo, 89-95.

14. Vesna and Nenad are pseudonyms. Like many other pre-war Sarajevans, my interlocutors were fierce opponents of nationalism, and they did not think that their ethnonational background in any way defined them. One of the possible ways of determining ethnonational background, however, was through names. In this sense the pseudonyms I have chosen reflect their real names, which had some importance during the siege.

15. For transmission and transformation of memories of the siege in Sarajevo, see Cornelia Sorabji, 'Managing Memories in Postwar Sarajevo: Individuals, Bad Memories, and New Wars', Journal of the Royal Anthropological Institute (N.S.) 2 (2006): 1-18.

16. On how precious water and a hot shower were, see Maček, Sarajevo, 64-6, 70-2.

17. For the life-sustaining importance of humour during the siege see ibid., 51-4. See also Srdjan Vucetic, 'Identity is a Joking Matter: Intergroup Humour in Bosnia', Spaces of Identity: An Interdisciplinary Journal 3 (2004): 1-28.

18. In contrast, for young people in present-day Sarajevo who yearn for a better future and life opportunities, these holes, filled with red colour after the war in order to commemorate the shelling of the city Together with commemorative plaques, are mostly a source of irritation; they symbolise being stuck in the past, in the war that they feel was not theirs and remains a major obstacle to a better future.

19. I propose the term 'secondary memory' because it captures well the phenomenon of transmitting memories of events to family members who did not experience them directly, in the same way as the term 'secondary traumatisation' captures the transmission of trauma within families. The term 'postmemory' carries the same sense; coined by literary scholar Marianne Hirsch in Family Frames: Photography, Narrative, and Postmemory (Cambridge, 1997), it has been used extensively. I propose to reserve 'postmemory' for broader phenomena, including the social and cultural context in which the understanding and remembrance of the past is negotiated, rather than using it within the limited family context.

20. On the randomness of dangers and irrational strategies for trying to ignore them, see Maček, Sarajevo, 31-51.

21. Nenad told me several other stories about incidents when he miraculously avoided dangers that his family members did not mention. 
22. For similar stories and observations during the siege, see Maček, Sarajevo, 62-89.

23. On inventiveness and pride during the siege, see ibid., 70-8.

24. Natan P.F. Kellermann, 'Psychopathology in Children of Holocaust Survivors: A Review of the Research Literature', Israel Journal of Psychiatry \& Related Sciences 38 (1984): 36-46.

25. Maček, Sarajevo, 89.

26. For more about Yugonostalgia during the siege, see ibid., 171.

27. Carol A. Kidron, 'Silent Legacies of Trauma: A Comparative study of Cambodian Canadian and Israeli Holocaust Trauma Descendant Memory Work', in Remembering Violence: Anthropological Perspectives on Intergenerational Transmission, ed. Nicolas Argenti and Katharina Schramm (New York and Oxford, 2010), 193-228; Yordanova, 'Intergenerational Transmission'.

28. Peter Gatrell, The Making of the Modern Refugee (Oxford, 2013), 118-47.

Open Access This chapter is licensed under the terms of the Creative Commons Attribution 4.0 International License (http://creativecommons.org/licenses/ by $/ 4.0 /$ ), which permits use, sharing, adaptation, distribution and reproduction in any medium or format, as long as you give appropriate credit to the original author(s) and the source, provide a link to the Creative Commons license and indicate if changes were made.

The images or other third party material in this chapter are included in the chapter's Creative Commons license, unless indicated otherwise in a credit line to the material. If material is not included in the chapter's Creative Commons license and your intended use is not permitted by statutory regulation or exceeds the permitted use, you will need to obtain permission directly from the copyright holder.

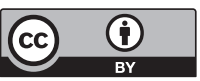

